\title{
PENGARUH KUALITAS PELAYANAN, FASILITAS, DAN HARGA TERHADAP KEPUASAN KONSUMEN PENGGUNA JASA TRANSPORTASI BUS DAMRI
}

\author{
Lesta Riana Sinaga ${ }^{*}$, Nur Efendi, M Iqbal Harori \\ Jurusan Ilmu Administrasi Bisnis, Fakultas Ilmu Sosial dan Politik, Universitas Lampung \\ * lestasinaga24@gmail.com
}

\begin{abstract}
The purpose of this study is to determine the effect of service quality, facilities, and price on consumer satisfaction of users of Damri bus transportation services. This research used explanatory research in quantitative approach. The number of samples used in this study are 100 respondents who use Damri bus transportation services, with Multiple linear regression analysis tool. The results of this study showed that there are significant influence on the variables of service quality, facilities and prices partially and simultaneously on consumer satisfaction of users of Damri bus transportation services.
\end{abstract}

Keywords: service quality, facilities, price, satisfaction

\begin{abstract}
ABSTRAK
Penelitian ini bertujuan untuk mengetahui pengaruh kualitas pelayanan, fasilitas dan harga terhadap kepuasan konsumen pengguna jasa transportasi bus Damri. Penelitian ini menggunakan pendekatan kuantitatif dengan jenis penelitian explanatory research. Sampel dalam penelitian sebanyak 100 orang responden pengguna jasa transportasi bus Damri, dengan teknik analisis data menggunakan regresi linier berganda. Hasil penelitian menunjukkan terdapat pengaruh yang signifikan secara parsial maupun simultan pada variabel kualitas pelayanan, fasilitas, dan harga terhadap kepuasan konsumen pengguna jasa transportasi bus Damri.
\end{abstract}

Kata kunci: kualitas pelayanan, fasilitas, harga, kepuasan

\section{PENDAHULUAN}

Moda transportasi di Indonesia dari tahun ke tahun semakin berkembang, baik transportasi darat, laut, udara, maupun transportasi pribadi dan publik. Transportasi adalah perpindahan manusia atau barang dari satu tempat ke tempat lainnya dengan menggunakan sebuah kendaraan yang digerakkan oleh manusia atau mesin (Divisiker dalam Junaidi, 2019:15). 
Pada transportasi publik khususnya, salah satu satu jenis transportasi yang banyak diminati oleh masyarakat umum adalah bus. Hal ini terlihat dari semakin meningkatnya jumlah penumpang bus dari tahun 2018 sampai 2019, sebagaimana terdapat dalam tabel 1 di bawah ini.

Tabel 1. Peningkatan Jumlah Pengguna Bus Tahun 2018-2019

\begin{tabular}{|c|c|c|}
\hline Tahun & Pengguna Bus & Banyak Bus \\
\hline 2018 & 4,51 Juta & 49.613 \\
\hline 2019 & 4.200 Juta & 50.317 \\
\hline
\end{tabular}

Sumber: Liputan 6, 21 Maret 2019.

Salah satu perusahaan penyedia jasa transportasi yang tersebar di seluruh Indonesia adalah Perum Damri (Perusaha Umum Djawatan Angkoetan Motor Repoeblik Indonesia). Sesuai dengan peraturan pemerintah Republik Indonesia nomor 31 tahun 1984 tentang Perum Damri, Perum Damri merupakan salah satu perusahaan umum yang didirikan oleh negara, yang diberi wewenang sebagai penyelenggara pemberi layanan jasa angkutan umum, penumpang, dan barang di atas jalan dengan kendaraan bermotor.

Perum Damri memiliki jaringan pelayanan yang tersebar hampir di seluruh wilayah Indonesia. Terdapat 33 kantor cabang Perum Damri di Indonesia, dengan jumlah armada mencapai hampir 3000 unit. Selain itu, Perum Damri semakin diandalkan untuk perjalanan dari dan menuju bandara. Layanan Damri Bandara ini telah tersedia di 22 Kota di Indonesia (Traveloka.com). Di Bandar Lampung sendiri, kantor Perum Damri berada di Jalan Kapt. Abd Haq, Raja basa, Kota Bandar Lampung.

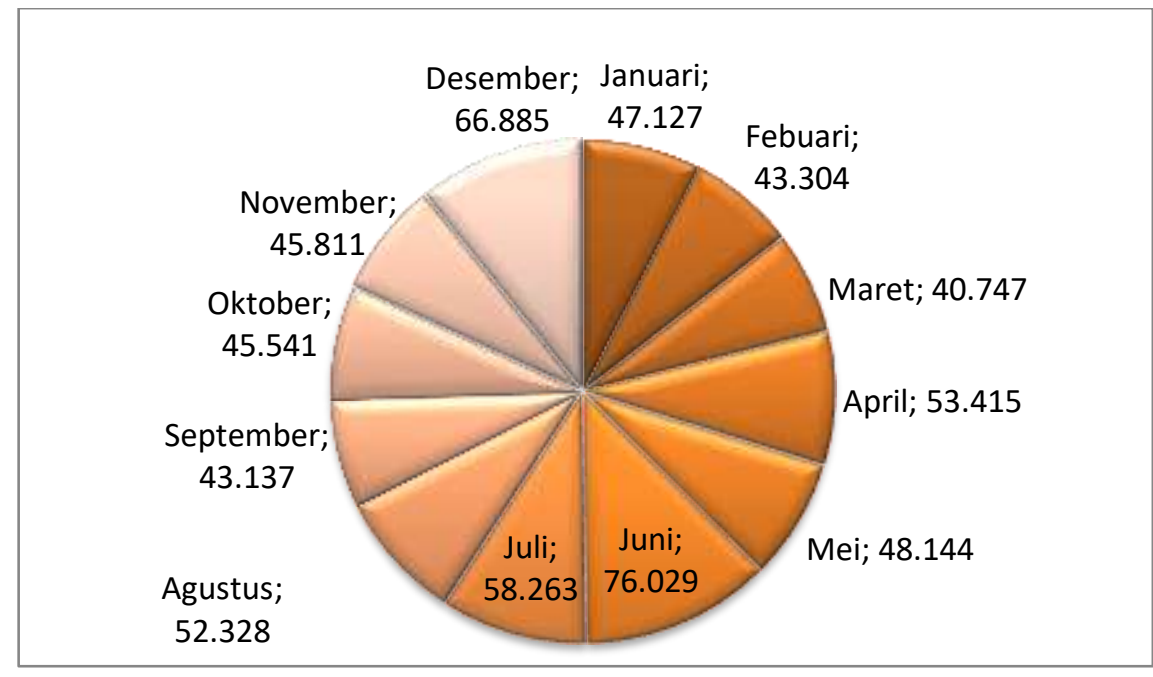

Gambar 1. Penjualan Tiket Damri Lampung tahun 2019

Sumber: Pengurus Perum Damri Lampung, 2019

Pada Kota Bandar Lampung khususnya, berdasarkan data penjualan tiket tahun 2019 (lihat gambar 1), terlihat penggunaan jasa transportasi Perum Damri cabang Bandar Lampung mengalami fluktuasi. Penjualan tiket tertinggi berada di bulan Juni dan bulan Desember. Hal ini dikarenakan pada bulan tersebut merupakan musim mudik hari raya/libur di Indonesia. Namun, pada umumnya jumlah pengguna jasa Perum Damri cabang Bandar Lampung selalu tinggi, jumlah pengguna terendah di bulan Maret saja 
setidaknya mencapai 40.747 penumpang.

Salah satu faktor yang menentukan tingkat keberhasilan dan kualitas perusahaan penyedia jasa adalah kemampuan perusahaan dalam memberikan pelayanan kepada pelanggan (Kotler dalam Diana, 2012:148). Kualitas pelayanan menjadi cara pelanggan membandingkan antara persepsi dengan layanan yang sesungguhnya yang diharapkan pelanggan. Apabila persepsi layanan yang diharapkan pelanggan lebih besar dari layanan yang sesungguhnya dirasakan, maka dapat dikatakan bahwa layanan tidak bermutu. Sedangkan, jika persepsi layanan yang diharapkan pelanggan lebih rendah dari layanan yang sesungguhnya diterima, maka dapat dikatakan bahwa layanan tersebut bermutu, dan apabila layanan yang diterima sama dengan layanan yang diharapkan, maka layanan tersebut dikatakan memuaskan.

Menurut Kotler (2012), kepuasan konsumen adalah hasil yang dirasakan oleh pembeli yang mengalami kinerja sebuah perusahaan yang sesuai dengan harapannya. Pelanggan merasa puas kalau harapan mereka terpenuhi, dan merasa amat gembira kalau harapan mereka terlampaui. Pelanggan yang puas cenderung tetap loyal lebih lama, membeli lebih banyak, kurang peka terhadap perubahan harga dan pembicaraannya mengutamakan perusahaan.

Selain pelayanan, fasilitas juga mempengaruhi kepuasan tersebut. Fasilitas adalah segala sesuatu berupa peralatan fisik yang disediakan oleh pihak penjualan jasa untuk mendukung kenyamanan konsumen (Kotler \& Keller dalam Haryanto, 2013:753). Berkaitan dengan fasilitas, Perum Damri merupakan satu-satunya jasa transportasi yang menyediakan 3 jenis layanan dan fasilitas yang berbeda-beda, yakni dari business, executive, dan royal class.

Faktor lainnya yang turut mempengaruhi kepuasan adalah harga. Harga seringkali digunakan sebagai indikator nilai, jika harga tersebut dihubungkan dengan manfaat yang dirasakan atas suatu barang atau jasa (Tjiptono \& Anastasia, 2016:219). Harga juga mengomunikasikan positioning nilai yang dimaksud dari produk atau merek perusahaan ke pasar. Produk yang dirancang dan dipasarkan dengan baik, dapat dijual dengan harga tinggi, dan menghasilkan laba yang besar (Kotler \& Keller, 2012:67).

Berdasarkan latar belakang tersebut, dapat disusun beberapa hipotesis dalam penelitian ini berkenaan dengan pengaruh kualitas pelayanan, fasilitas, dan harga terhadap kepuasan konsumen:

1. Ha1: Terdapat pengaruh signifikan kualitas pelayanan terhadap kepuasan konsumen.

2. Ha2: Terdapat pengaruh signifikan fasilitas terhadap kepuasan konsumen.

3. Ha3: Terdapat pengaruh signifikan harga terhadap kepuasan konsumen.

4. Ha4: Terdapat pengaruh secara simultan kualitas pelayanan, fasilitas, dan harga terhadap kepuasan konsumen.

\section{METODE PENELITIAN}

Penelitian ini merupakan explanatory research dengan pendekatan kuantitatif. Explanatory research merupakan penelitian yang bertujuan untuk menjelaskan fenomena yang ada (Jogiyanto, 2009:12), yakni menjelaskan hubungan kausal antar variabel dengan menguji hipotesis yang telah dirumuskan sebelumnya. Sampel dalam penelitian ini 
berjumlah 100 responden pengguna jasa bus Damri Lampung trayek bus antar kota Lampung-Jakarta, dengan teknik accidental sampling. Data dianalisis dengan menggunakan analisis deskriptif, uji asumsi klasik, analisis regresi linier berganda (uji $\mathrm{t}$, uji $\mathrm{F}$, dan koefisien determinasi).

\section{HASIL PENELITIAN}

\section{Analisis Statistik Deskriptif}

Berdasarkan hasil analisis deskriptif, dapat diketahui 100 responden dalam penelitian ini terdiri dari pria sebanyak $41 \%$, dan wanita $59 \%$, dengan rentang usia 21-30 tahun $(71 \%), 15-20$ tahun $(20 \%), 31-40$ tahun $(5 \%), 41-50$ tahun $(4 \%)$. Sebagian besar pekerjaan responden adalah pelajar/mahasiswa (68\%), sisanya wiraswasta (25\%), PNS $(5 \%)$, dan lainnya (2\%), dengan penghasilan didominasi di bawah 1 juta rupiah. Sebagian besar responden adalah pengguna jasa transportasi bus Damri dua/lebih dari dua kali $(66 \%), 34 \%$ responden adalah pengguna jasa transportasi bus Damri yang baru pertama kalinya. Layanan yang pernah digunakan responden saat menggunakan jasa transportasi bus damri: $27 \%$ adalah pengguna royal class, executive (26\%), business (19\%), dan pernah menggunakan semua layanan $(28 \%)$.

\section{Uji Asumsi Klasik}

\section{Uji Normalitas}

Uji normalitas digunakan untuk menguji apakah model regresi berdistribusi normal atau tidak. Model regresi yang baik adalah berdistribusi normal. Pengujian normalitas dapat dilakukan dengan menggunakan uji Kolmogorov-smirnov test dan grafik normal plot. Jika tingkat signifikan probabilititas >0,05 maka data penelitian berdistribusi normal (Ghozali, 2011:160). Berikut ini hipotesis yang digunakan untuk melakukan uji normalitas: Ho: nilai probability $>5 \%$, maka berdistribusi dengan normal Ho: nilai probabiliti < 5\%, maka berdistribusi tidak normal

Berdasarkan hasil uji normalitas, besarnya nilai difference positive adalah 0,097, sedangkan difference negative adalah -0,098. Adapun nilai Kolmogorov-Smirnov adalah 0.976, dengan signifikasi 0.297, yang berarti data residual berada di atas 0.05, dan terdistribusi normal.

\section{Uji Heteroskedastisitas}

Pengujian terhadap heteroskedastisitas menurut Priyanto (2011:93), dapat dilakukan melalui pengamatan terhadap pola scatterplots, jika membentuk pola tertentu, maka model regresi memiliki gejala heteroskedastisitas. Munculnya heteroskedastisitas menunjukkan bahwa penaksiran dalam model regresi tidak efisien dalam sampel besar maupun kecil. Berdasarkan gambar 3, menunjukkan bahwa scatterplots tidak membentuk pola tertentu, sehingga model regresi tidak mengalami gejala heteroskedastisitas. 


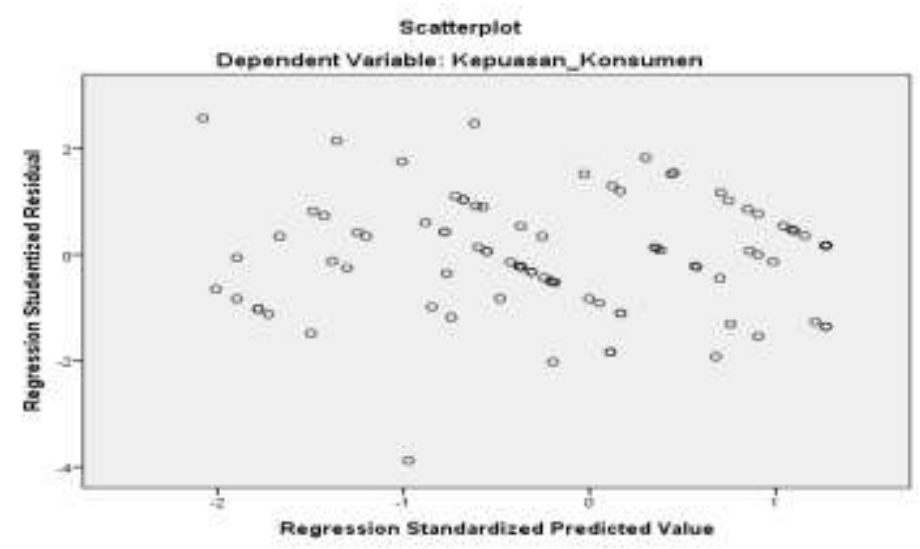

Gambar 3. Grafik Scatterplots Heteroskedastisitas Sumber: Data Diolah, 2020

\section{Analisis Regresi Linier Berganda}

Berdasarkan hasil analisis regresi linier berganda pada tabel 2, maka dapat disusun persamaan regresi sebagai berikut:

$$
\begin{gathered}
Y=\alpha+\beta_{1} X 1+\beta_{2} X 2+\beta_{3} X 3+e \\
\mathrm{Y}=2,438+0,120 \mathrm{X}_{1}+0,241 \mathrm{X}_{2}+0,386 \mathrm{X}_{3}+e
\end{gathered}
$$

Persamaan tersebut menjelaskan bahwa:

1. Nilai konstanta sebesar 2,438 , artinya jika kualitas pelayanan, fasilitas, dan harga bernilai 0 atau tidak ada, maka kepuasan konsumen sebesar 2,438.

2. Koefisien regresi linier berganda Kualitas Pelayanan (KP) bernilai positif (+) sebesar 0,120. Berarti setiap terjadi kenaikan nilai 1 satuan dari variabel kualitas pelayanan, maka kepuasan konsumen akan mengalami peningkatan sebesar 0,120.

3. Koefisien regresi linear berganda Fasilitas (F) bernilai positif (+) sebesar 0,241. Berarti setiap terjadi kenaikan nilai 1 satuan dari variabel fasilitas, maka kepuasan konsumen akan mengalami peningkatan sebesar 0,241 .

4. Koefisien regresi linear berganda Harga $(\mathrm{H})$ bernilai positif $(+)$ sebesar 0,386 . Berarti setiap terjadi kenaikan nilai 1 satuan dari variabel harga, maka kepuasan konsumen akan mengalami peningkatan sebesar 0,386.

Tabel 2. Hasil Regresi Linier Berganda

\begin{tabular}{|l|r|r|}
\hline \multirow{2}{*}{ Model } & \multicolumn{2}{|c|}{ Unstandardized Coefficients } \\
\cline { 2 - 3 } \multicolumn{1}{|c|}{ (Constant) } & \multicolumn{1}{|c|}{ S } & .973 \\
\hline Kualitas Pelayanan (KP) & 2.438 & .055 \\
\hline Fasilitas (F) &, 120 & .071 \\
\hline Harga (H) &, 241 & .439 \\
\hline
\end{tabular}

Uji Hipotesis

Uji Parsial (Uji t)

Pengujian ini dilakukan untuk mengetahui ada tidaknya pengaruh masing-masing variabel bebas terhadap variabel terikat. 
Tabel 3. Hasil Uji T

\begin{tabular}{|l|c|r|r|c|}
\hline \multicolumn{1}{|c|}{ Model } & $\mathbf{T}_{\text {hitung }}$ & $\mathbf{t}_{\text {tabel }(0,05)}$ & \multicolumn{1}{c|}{ Sig } & Keterangan \\
\hline Kualitas Pelayanan & 2,504 & 1,98498 &, 014 & Signifikan \\
\hline Fasilitas & 3,402 & 1,98498 &, 033 & Signifikan \\
\hline Harga & 4,934 & 1,98498 & 0,000 & Signifikan \\
\hline
\end{tabular}

Sumber: Data Diolah, 2020

Berdasarkan hasil uji t pada tabel 3, dapat dijelaskan sebagai berikut:

1. Hasil perhitungan pada variabel kualitas pelayanan (X1) diperoleh nilai $t_{\text {hitung }}=$ 2,504, sedangkan nilai ttabel $=1,98498$, dengan nilai sig 0,014<0,05. Artinya, На diterima dan Ho ditolak, sehingga terdapat pengaruh yang signifikan kualitas pelayanan terhadap kepuasan konsumen.

2. Hasil perhitungan pada variabel fasilitas (X2) diperoleh nilai $t_{\text {hitung }}=3,402$, sedangkan nilai ttabel=1,98498, dengan nilai sig 0,033<0,05. Artinya, Ha diterima dan Ho ditolak, sehingga terdapat pengaruh yang signifikan fasilitas terhadap kepuasan konsumen;

3. Hasil perhitungan pada variabel harga (X3) diperoleh nilai thitung $=4,934$, sedangkan nilai tabel=1,98498, dengan nilai sig 0,000<0,05. Artinya, Ha diterima dan Ho ditolak, sehingga terdapat pengaruh yang signifikan harga terhadap kepuasan konsumen.

\section{Uji Simultan (Uji F)}

Uji F merupakan pengujian yang dilakukan untuk mengetahui adanya pengaruh semua variabel bebas terhadap variabel terikat secara bersama-sama (simultan).

Tabel 4. Hasil Uji F-Statistik

\begin{tabular}{|c|c|c|c|}
\hline$F_{\text {hitung }}$ & $\mathrm{F}_{\text {tabel }}$ & P value & Keterangan \\
\hline 84,078 & 2.70 & 0,00 & Ho ditolak Ha diterima \\
\hline
\end{tabular}

Pada perhitungan uji F di tabel 4, diperoleh F-hitung sebesar 87,078, dengan tingkat signifikansi 0,000. Sedangkan nilai F-tabel pada tingkat kepercayaan 95\% dengan derajat kebebasan 5\% adalah sebesar 2,70. Dengan demikian, nilai F-hitung $>$ F-tabel $(87,078>2,70)$. Artinya, Ha diterima dan Ho ditolak, sehingga terdapat pengaruh secara simultan antara kualitas pelayanan, fasilitas, dan harga terhadap kepuasan konsumen.

\section{Koefisien Determinasi}

Koefisien Determinasi $\left(\mathrm{R}^{2}\right)$ bertujuan untuk melihat besarnya persentase pengaruh variabel $X$ terhadap naiknya variabel $Y$, sedangkan sisa nya atau selisih dari $100 \%$ adalah pengaruh yang disebabkan oleh faktor lainya yang tidak diteliti dalam penelitian ini.

Tabel 5. Koefisien Determinasi

\begin{tabular}{|c|c|c|c|}
\hline Model & $\mathrm{R}$ & $R$ Square & Adjusted $R$ Square \\
\hline 1 & $0.851^{\mathrm{a}}$ & 0.724 & 0,716 \\
\hline
\end{tabular}

a. Predictors: (Constant), Kualitas Pelayanan, Fasilitas dan Harga

b. Dependent Variable: Kepuasan Konsumen 
Sumber: Data Diolah (2020)

Berdasarkan hasil koefisien determinasi pada tabel 5, menunjukan besarnya kontribusi variabel kualitas pelayanan (X1), fasilitas (X2), dan harga (X3) terhadap variabel kepuasan konsumen $(\mathrm{Y})$ adalah 0,724 atau $72,4 \%$. Adapun sisa nya sebesar 0,276 atau $27,6 \%$, dijelaskan oleh faktor-faktor lain yang tidak diteliti pada penelitian ini. Selain itu, didapatkan nilai $\mathrm{R}$ sebesar 0,851, nilai tersebut pada tabel interpretasi nilai $\mathrm{r}$, masuk dalam kategori hubungan yang "sangat kuat".

\section{PEMBAHASAN}

\section{Pengaruh Kualitas Pelayanan terhadap Kepuasan Konsumen}

Berdasarkan hasil analisis regresi linier berganda, koefisien regresi variabel kualitas pelayanan (KP) sebesar 0,120 , dengan arah hubungan positif $(+)$, artinya apabila kualitas pelayanan (X1) mengalami peningkatan sebesar 1\%, maka akan meningkatkan kepuasan konsumen $(\mathrm{Y})$ sebesar 12\%, Hasil uji t variabel kualitas pelayanan (X1), diperoleh nilai $t_{\text {hitung }}=2,504>t_{\text {tabel }}=1,98498$, dengan nilai sig 0,014<0,05. Artinya, Ha diterima dan Ho ditolak, sehingga terdapat pengaruh yang signifikan kualitas pelayanan terhadap kepuasan konsumen.

Hasil penelitian tersebut sejalan dengan penelitian yang dilakukan oleh Taufiqurrohman (2017), bahwa terdapat hubungan kualitas pelayanan dengan kepuasan pengguna jasa transportasi.

\section{Pengaruh Fasilitas terhadap Kepuasan Konsumen}

Berdasarkan hasil analisis regresi linier berganda, koefisien regresi variabel fasilitas (F) sebesar 0,241, dengan arah hubungan positif (+), artinya apabila fasilitas (X2) mengalami peningkatan sebesar 1\%, maka akan meningkatkan kepuasan konsumen (Y) sebesar 24,1\%. Hasil uji t variabel variabel fasilitas (X2), diperoleh nilai thitung sebesar $3,402>t_{\text {tabel }}$ sebesar 1,98498, dengan nilai sig 0,33<0,05. Artinya, Ha diterima dan Ho ditolak, sehingga terdapat pengaruh yang signifikan fasilitas terhadap kepuasan konsumen.

\section{Pengaruh Harga terhadap Kepuasan Konsumen}

Berdasarkan hasil analisis regresi linier berganda, koefisien regresi variabel harga (X3) sebesar 0,386, dengan arah hubungan positif (+), artinya apabila harga (X3) mengalami peningkatan sebesar $1 \%$, maka akan meningkatkan kepuasan konsumen (Y) sebesar $38,6 \%$. Hasil uji t variabel variabel harga $(X 3)$, diperoleh nilai $t_{\text {hitung }}=4,034>t_{\text {tabel }}$ $=1,98498$, dengan nilai sig 0,000<0,05. Artinya, Ha diterima dan Ho ditolak, sehingga terdapat pengaruh yang signifikan harga terhadap kepuasan konsumen.

Hasil penelitian ini didukung dengan penelitian yang dilakukan oleh Wulan \& Eva (2018) bahwa harga atau tarif berpengaruh terhadap kepuasan konsumen, baik secara parsial maupun simultan.

Pengaruh Kulitas Pelayanan, Fasilitas, dan Harga terhadap Kepuasan Konsumen

Hasil uji $\mathrm{F}$ variabel kualitas pelayanan, fasilitas, dan harga terhadap kepuasan konsumen menunjukkan nilai $\mathrm{F}_{\text {hitung }}=84,078>\mathrm{F}_{\text {tabel }}=2,70$, maka Ha diterima, dan Ho 
ditolak, artinya kualitas pelayanan, fasilitas, dan harga memiliki pengaruh signifikan terhadap kepuasan konsumen. Hasil uji determinasi menunjukkan kontribusi yang cukup besar variabel kualitas pelayanan, fasilitas, dan harga terhadap kepuasan konsumen sebesar $72,4 \%$, dengan nilai hubungan yang sangat kuat $(0,851)$.

\section{KESIMPULAN}

Berdasarkan hasil analisis, dapat disimpulkan bahwa secara parsial maupun simultan terdapat pengaruh kualitas pelayanan, fasilitas, dan harga terhadap kepuasan konsumen. Nilai pengaruh terbesar terdapat pada variabel harga. Dengan demikian, pengguna jasa transportasi bus Damri cabang Lampung trayek bus antar kota LampungJakarta, menilai variabel harga sebagai variabel terbesar yang menentukan kepuasan mereka, lalu diikuti dengan fasilitas apa yang didapatkan dengan harga yang ditawarkan. Sehingga, perlu adanya kebijakan tarif yang mampu bersaing dibandingkan kompetitor sejenis dalam trayek yang sama, dan dukungan fasilitas yang unggul pada kelas harga yang ditawarkan. Perlu dikembangkan penelitian lebih lanjut untuk mengetahui faktorfaktor lainnya yang mempengaruhi kepuasan konsumen pengguna jasa transportasi, khususnya berkenaan dengan isu keamanan dalam menggunakan jasa transportasi publik terhadap kepuasan konsumen.

\section{DAFTAR PUSTAKA}

Ghozali, I. (2011). Aplikasi analisis multivariate dengan program SPSS. Semarang: Badan Penerbit Universitas Diponegoro.

Jogiyanto. (2009). Penguatan moda transportasi lokal dalam mendukung Kabupaten Pulau Morotai sebagai destinasi wisata unggulan. Jurnal Wilayah dan Lingkungan, 7(1), 14-25.

Kotler, P., \& Keller, K. L. (2012). Manajemen Pemasaran. Edisi 12. Jakarta: Erlangga.

Kotler, P., \& Keller, K. L. (2013). Manajemen Pemasaran. Edisi 13, Jilid 2. Jakarta: Erlangga.

Tjiptono, F. \& Anastasia, D. (2016). Pemasaran Esensi dan Aplikasi. Yogyakarta: Penerbit Andi. 